\title{
The Hydro-geomorphological Implications of Urbanisation in Bamenda, Cameroon
}

\author{
Sunday Shende Kometa ${ }^{1} \&$ Ndi Roland $\mathrm{Akoh}^{2}$ \\ ${ }^{1}$ Department of Geography, FSMS, University of Buea, Buea, Cameroon \\ ${ }^{2}$ Department of Geography, University of Yaounde, Yaounde, Cameroon \\ Correspondence: Sunday Shende Kometa, Department of Geography, FSMS, University of Buea, P.O. Box 63, \\ Buea Cameroon. E-mail: shendek@hotmail.com
}

Received: March 7, $2012 \quad$ Accepted: May 1, 2012 Online Published: May 24, 2012
doi:10.5539/jsd.v5n6p64
URL: http://dx.doi.org/10.5539/jsd.v5n6p64

\begin{abstract}
Rapid urbanization and proper urban planning are two variables in the equation of environmental stability. In Bamenda municipality these have been moving in opposite directions. This indicates the lopsidedness in which the problems of urban planning and urban development, masterminded by urbanization have been handled over time. This paper therefore examines the pattern of urbanization and urban development in the Bamenda area, with respect to the implication on the hydrology, geomorphology and sustainable urban space management. The study made use of primary and secondary sources to collect the necessary data. The results show that Bamenda started experiencing a rapid rate of urbanisation and urban development from the 1980s. This forced many people especially the poor to reside in cheap marginal areas which naturally constitute the pathways for catastrophic hydrological and geomorphological phenomena. Although these hazards originate from natural systems and mechanisms, anthropogenic modifications spearheaded by urbanisation have reinforced the frequency and magnitude of certain hazards like floods and landslides. In order to mitigate these hydro-geomorphologic problems, the study recommends the development of an alternative land use system on occupied slopes and flood plains, the creation of levees and the construction of adequate storm drains.
\end{abstract}

Keywords: hydro-geomorphology, urbanization, environmental impact

\section{Introduction}

With more than half of the world's population now living in urban areas, this is truly an urban century (United Nation Bulletins, 2008). The proportion of people living in cities in all regions is rising. Growth in population is widely recognized as one of the most clear-cut driving forces behind increased human impact on the environment. A prominent feature of population redistribution particularly in developing countries is the growth of major cities. Natural increase accounts for about $60 \%$ of this urban growth though the rate of growth is faster in developing countries. By 2030, for example, it is expected that nearly 5 billion people (61\%) of the world's total of 8.1 billion people will live in cities with accelerated impacts on the environment (Park, 2001). An increase in the world population alongside widespread urbanization associated with advances in technology and related developments of economic, political and social structures have all combined to make the interaction between humankind and nature very different from the situation a few decades back. The interaction between man and his environment has been more apparent in an urban centre. The city thus poses a challenge to those concerned with the exploitation of its resources and concomitant environmental quality. The transition of urban watersheds from their natural, forested state to a predominantly urban condition encompasses the removal of vegetation, compaction of soil, creation of impervious surfaces and alteration of natural drainage networks. In fact, the level of urbanization in urban watersheds has shown no systematic planning at all.

Bamenda Town's history goes as far back as 1901 when the first German Station built in Bali in 1890 was transferred to Bamendankwe village (German Fort). Most metropolitan areas in general and Bamenda in particular face the problem of urban sprawl, loss of the natural vegetation, as well as a decline in the extent and connectivity of wetlands and wildlife habitat. Bamenda has changed from a small, isolated population cluster in the past to a large inter-connected economic and urban centre. Urban growth and the concentration of people in this urban area have created societal as well as environmental problems. There have therefore been phenomenal rates in the magnitude and changing patterns of urban population growth, creating extensive urban landscapes. 
As the exploding population in Bamenda presses on the limited resource base for its needs and activities, the challenge of providing a healthy living environment clearly becomes greater.

Between 1900 and 1960, the processes of urbanisation and urban development were considerably slow in Bamenda. Consequently, the intensity of human impact on the environment was exiguous to warrant a study of this magnitude. It also seemed, the occurrence of hydrological as well as geomorphological hazards was a theoretical rather than a practical reality, judging from current trends. Many of the farmlands, wetlands, and forests that existed in the 1950s have over the past decades been transformed into urban settlements. Bamenda experienced a rapid evolution in its urban landscape during this period. This could be accounted for by the fact that its status as provincial capital, which was lost for some time and replaced with that of district seat was recovered upon the occasion of the 1972 Referendum. Consequently, there was an increase in the urban population and the development of settlements.

From 1960 to 1980, Bamenda experienced a profound evolution of its urban landscape. This was due to the change in its administrative status from a district seat to the provincial capital of the then North West Province. This resulted in the massive influx of civil servants (Table 1). Between 1980 and 2010, the expansion of the Bamenda urban space reached its crescendo. As a matter of fact, the agro-pastoral show in 1984 and the twin visits of the president of the Republic of Cameroon (1982 and 1985) gave Bamenda what she lacked most in the domain of paved roads and tele-communication systems. Due to the rapid and uncontrolled rate of urbanisation and urban development, the Bamenda Master Plan was created. This was aimed at giving a geographical expression to the economic, social and cultural practices in this urban milieu. Therefore, the Master Plan was aimed at ensuring a balanced urban development. However, the implementation of this Master Plan saw its doom partly due to the economic crisis that hit Cameroon in the late 1980s as well as the ever increasing population into this lone primate city of the North West Region. Most green spaces were rapidly colonized. Besides, the rate at which people encroached on marginal lands such as steep slopes and marshy areas increased at an incredible rate. Therefore, urban hydrological as well as geomorphological hazards became the order of the day.

Table 1. Population in different quarters of Bamenda (1976 and 1980)

\begin{tabular}{cccc}
\hline Quarters & Population in 1980 & Percentage change & Population in 1976 \\
\hline Small Mankon & 4030 & 6.9 & 5065 \\
Old Town & 7300 & 12.5 & 6446 \\
Bayelle & 5790 & 9.9 & 2088 \\
Nkwen & 6730 & 11.5 & 6102 \\
Ntamulung & 2450 & 19.0 & 5462 \\
Ntarinkon & 4780 & 8.2 & 4920 \\
Azire & 4500 & 7.5 & 5146 \\
Metta - Atuakom & 7540 & 12.4 & 2712 \\
Station Mendankwe & 5730 & 9.8 & $?$ \\
Mbatu & 880 & 1.5 & $?$ \\
Total & 58400 & 100.00 & 41508 \\
\hline
\end{tabular}

The table shows the population and percentages growth rates for different residential quarters in the Bamenda Municipality in 1976 and 1980. Source: Ministry of Urban Development and Housing (1985)

\section{The Study Area}

Bamenda is located between latitudes $5^{\circ} 56^{\prime \prime} \mathrm{N}$ and $5^{\circ} 58^{\prime \prime}$ North of the equator and longitude $10^{\circ} 09^{\prime \prime}$ and $10^{\circ} 11^{\prime \prime}$ East of the Greenwich Meridian. Bamenda lies at an altitude of $1430 \mathrm{~m}$ above sea level with a surface area of 3125ha (Acho-Chi, 1998). The town occurs along the Cameroon Volcanic Line and exhibits two very distinct relief environments; that is, the High Lava plateau (Up Station) with an altitude of about $1400 \mathrm{~m}$ and the Lower plateau (Down Town) with an average altitude of $1100 \mathrm{~m}$ above sea level. Bamenda is the regional head quarters of the North West Region of Cameroon. The vegetation is the Guinea Savanna type and the temperature is moderate (Neba, 1999). There are two main seasons; the rainy and the dry season. The rainy season is generally 
longer and lasts for eight months (mid March to mid October). Absolute annual average precipitation ranges from $1700 \mathrm{~mm}$ to $2824 \mathrm{~mm}$. The major wind systems affecting this region are the north east trades (Harmattan haze) and the south west monsoon that brings rain. Rainfall is heavy and therefore destructive. The topography is hilly.

Bamenda is underlain by granites and gneiss of the Precambrian era. There is also a cover of basaltic rocks. The rocks range from volcanic rocks to sedimentary rocks like clay and silt along the flood plains of the River Mezam. An important geomorphic feature in Bamenda is the "Bamenda escarpment". Due to the increasing rate of urbanization and ecological marginalization, the urban poor have been forced to colonize and cultivate these marginal hillsides. According to Ndenecho and Eze (2004), the escarpment is made up of volcanic rocks called trachyte. The dominant soil types are the lateritic soils which are reddish in colour. The erodibility of these soils encourages torrent processes and is one of the factors responsible for the presence of gullies on bare surfaces. The valleys are covered with alluvium washed from the escarpment. The relief of Bamenda has greatly influenced the drainage of the region. Very few rivers and streams drain the area. The most important is the River Mezam (and its tributaries) which flows from the Bamenda escarpment through the city centre and passes through the village of Mankon. The Ayaba and Liberkan Streams feed the River Mezam. These streams have a dendritic pattern. Human activities in the municipality include primary (basically subsistence agriculture) secondary and tertiary activities. It is inevitably a centre of (political) power, government, higher education, research and cultural facilities.

\section{Material and Methods}

A reconnaissance survey was undertaken in the months of August and September 2009 to have an understanding of the spatial setting of the town and also to identify the different geomorphological as well as hydrological hazards inherent in the study area. These included landslides, floods, water pollution, accelerated erosion and gully formation. Given the fact that the occurrence of landslides and floods was common during this period, their study and spatial occurrence were given particular attention. The study of landslide was done through the observation of the rock types as well as the estimation of the angles of slope and gradients. The depths of various landslide scars were measured. The nature of human activities around these hazardous sites were also examined. To simplify and facilitate the task of collecting data in the field, the municipality was divided into zones. Each zone was visited and the intended assignment completed before another zone was visited, to avoid mix-ups and errors.

A Global Positioning System (GPS) aided in producing a landslide hazard zonation map. Every feature recorded by the GPS was registered in the corresponding way point forms designed for the field work. At the end of each day, data brought from the field was downloaded into the computer according to the filling system and file formats. The data was processed with one of the widely used GIS software- arc view 3.2. Attribute information describing all the features recorded were exported to arc view for GIS analysis. All features not well recorded with the GPS were re-georeferenced. Four factors; namely, past history, slope steepness, bed rock and human factors were used to assess the landslide hazard. The hydrologic factor was added to reflect the important role which ground water plays in the occurrence of landslides in the area.

In producing the landslide hazard zonation map the following map sources were consulted; land use, relief, geology and topography. This map was used as a tool to help identify those areas which could be affected by a damaging landslide and assess the probability of landslide over time. This will aid in sustainable urban planning and effective urban space management. For floods, a study was carried out to determine the spatial distribution of flood-prone areas in different neighbourhoods in Bamenda. This was done through the observation of different flood phenomena and possible causes. The extent to which rivers and streams overspill their banks as well as the heights of flood waters on buildings were noted. Field tracking was done with the use of a GPS to aid in the production of a flood map for Bamenda. Data obtained from the GPS were super - imposed on the satellite image of Bamenda and the affected houses were digitized as polygons. This was done with the aid of a hydrological map adapted from the satellite imagery. Questionnaires were administered using stratified systematic random sampling in residential quarters known for hydro-geomorphic hazards. A total of 20 questionnaires were administered in each neighbourhood. Different land use activities inherent in the study area such as settlements, agriculture and forests were given particular attention.

A number of library sources, journals as well as published and unpublished articles (from the Ministry of Urban Development and Housing, Environment and Nature Protection and the Ministry of State Property and Land Tenure) were consulted. Semi-guided interviews were also conducted with the Government Delegate of Bamenda City Council, the Delegate of Urban Development and Housing as well as the Divisional Delegate of 
Environment and Nature Protection. Rainfall data for Bamenda was obtained from the North West Regional Station for Meteorology. This provided data for rainfall intensity, duration and variation over the years. Furthermore, rainfall data for number of days preceding the occurrence of major floods and landslides events were thoroughly examined. Considering the frequency of floods and landslides, the rise in the level of flood waters was examined alongside efficiency of the size of storm drains.

The standard deviation was used to determine the average variation of rainfall distribution from the mean. This was done in order to determine the timing and the return periods of heavy rainfall and the occurrence of floods and landslides in Bamenda. The period from the year 2000 to 2009 was chosen given the availability of rainfall data for Bamenda. Furthermore, the coefficient of variation (CV) was calculated in order to determine the reliability of rainfall. This was done using the standard deviation to establish a correlation between rainfall amounts and the occurrence landslides. The chi square test of significance was used because the data collected were basically frequencies on the perceptions of respondents with respect to urbanization and flooding in the Bamenda Municipality.

\section{Findings}

The high rate of urbanisation in Bamenda has not been consistent with a sustainable urban planning scheme. Law No. 2004/003 of 21/04/2004 laid down the basis to regulate town planning in Cameroon. A critical look at the land use map of Bamenda town in 1980 (Figure 1) and that in 2010 (Figure 2) reveals that most, if not all of these provisions have been largely ignored. Many housing structures have been erected where they are not supposed to be or even if they are where they should be, they do not conform to the laid down norms. By the year 2010 over $34.4 \%$ of green spaces had been occupied. In fact, most green spaces around Nkwen and Mulang residential quarters had been rapidly invaded.

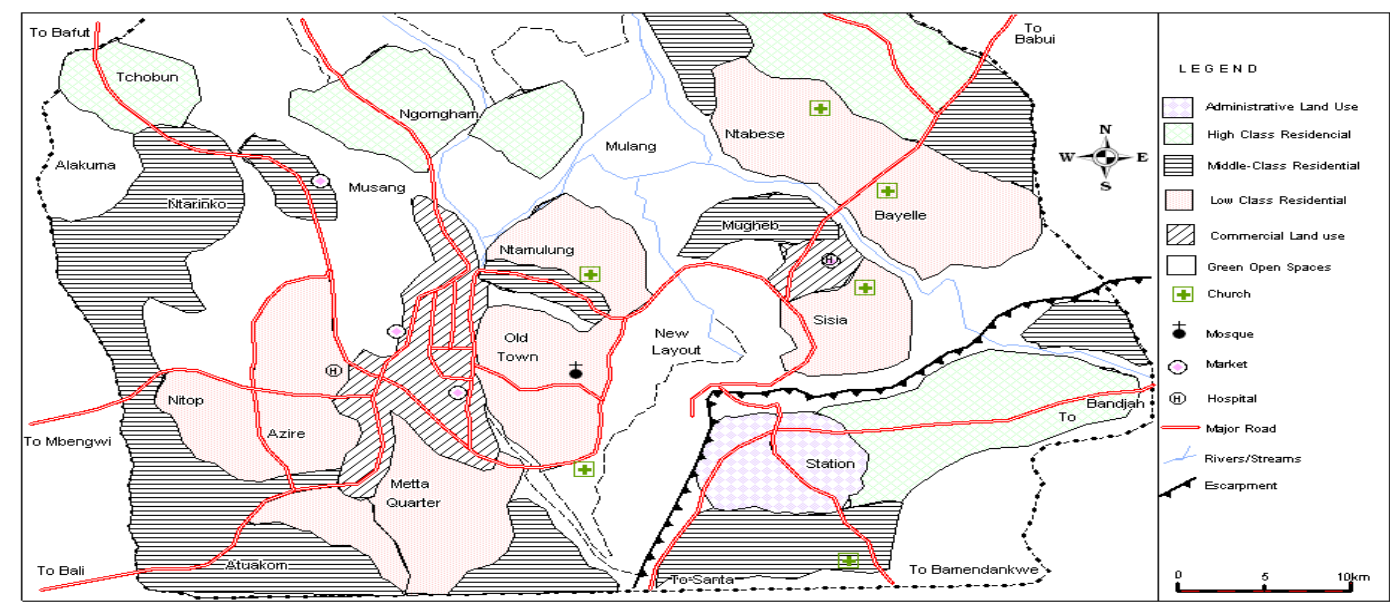

Figure 1. Bamenda land use map (1980)

The figure is the land use map for Bamenda in 1980. The map was produced by the Bamenda City Council in 2008. Source: Bamenda City Council (2008) 


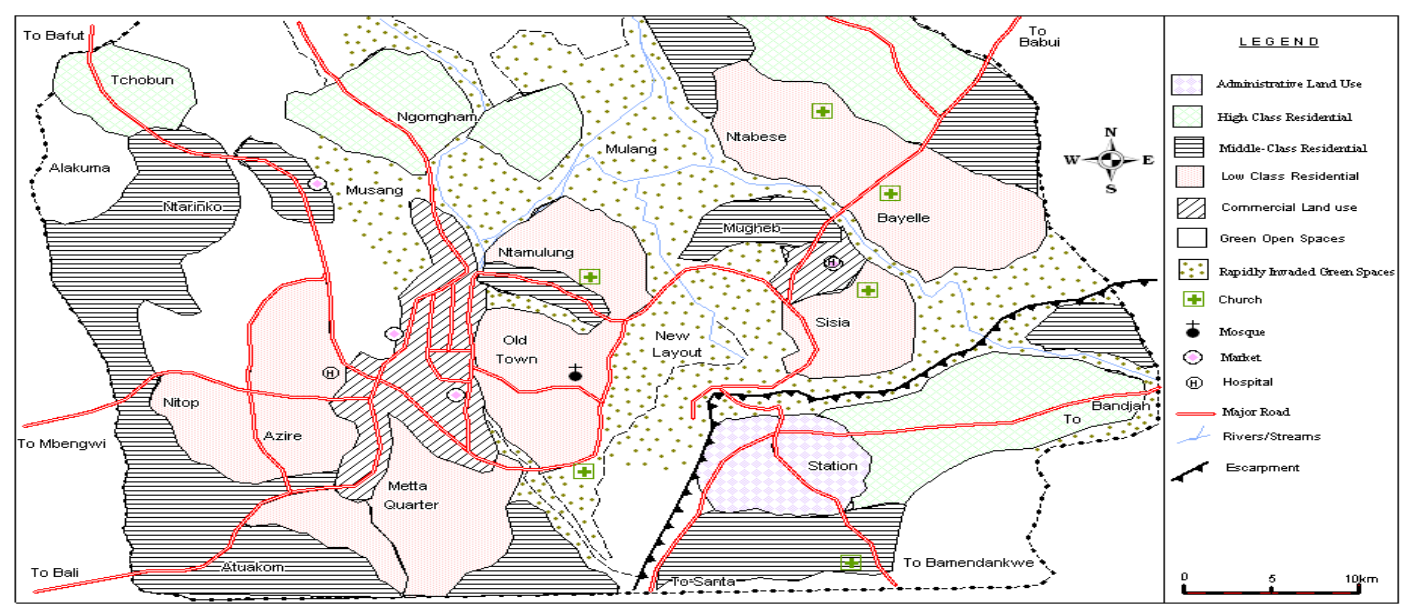

Figure 2. Bamenda land use map (2010)

The figure is the land use map for the Bamenda City Area. It has been adapted from the Bamenda land use map of 1980. Source: Adapted from Bamenda Land Use Map (1980)

Consequently, there is the preponderance of a large proportion of urban dwellers living in hazardous housing and environmental conditions. The gradual encroachment on the slopes of the escarpment increased the intensity and magnitude of mass wasting processes especially landslides. Between 6-8 percent of the population in Bamenda live in informal settlements developed on steep slopes and around 20 percent live on flood plains. A participatory approach to urban planning is still a far-fetched dream. Thus, many disgruntled urbanites, neglect the plan and resort to the development of open spaces which largely do not conform to urban planning norms. The process of urban planning and zoning has been slow or stagnant, if not lopsided. Given this current debacle, turmoil and spectacle of urbanisation and urban development in Bamenda, urban geomorphological as well as hydrological hazards have surfaced in untold proportions. Consequently, this conforms with the hypothesis that the increased frequency of hydro-geomorphic hazard is masterminded by lapses in urban planning and implementation. The fast-growing complexities of unbalanced urban development, population growth and impending threat on the habitation of fragile areas led to the speedy deterioration of environmental properties making the contemporary 'Bamenda Man' ever more resource conscious. In this vein, urban development in Bamenda has not only failed in its objective to ensuring an effective planning of this town but has also failed to interweave the environmental, developmental as well as sustainable threads in a common tapestry.

Urbanization has had severe impacts on the hydrology of Bamenda through the creation of roads, settlements and the generation and the dumping of wastes in river and stream courses. The severity of flooding has been magnified by human activities in Bamenda. Excessive deforestation on the Bamenda escarpment has consequently accelerated runoff. The constant occurrence of floods in Bamenda can partly be attributed to flaws in urban planning as well as extreme physical conditions with precipitation being the primate or the immediate trigger. The spatial distribution of flood-prone zones in Bamenda reveals a situation in which the convergence between floods hazards and vulnerability is obvious. Areas with high flood risks in Bamenda include flood plains and wet lands. These are areas located close to streams and rivers where human activities have increased the frequency and intensity of floods. These areas include Mulang, Musang, Lower Ngomgham, Below Foncha, Old Town, Bayelle, Ntamulung and Musang.

As shown on Figure 3, a greater proportion of respondents in selected flood-prone areas in Bamenda were of the opinion that floods in Bamenda occur in the month of August. A greater proportion of the population at Mulang are of the opinion that floods are common in the month of July (30\%). At Ntamulung, $40 \%$ of the respondents held the view that flood occurrence is common in the month of September, followed by August, July, and June. From the presentations of rainfall data for 2005, 2006, 2007, 2008 and 2009, it is, glaring that the peak periods in which maximum rainfall occur (in the five years under study) are in the months of July, August and September. These periods as noted have always coincided with the occurrence of floods in Bamenda. Taking 2009 as a classical example, it was realized that the highest amount of rainfall occurred on 4th August. This led to serious inundation to the extent that two people lost their lives. The total number of rainy days for the period $2005-$ 2009 was examined in order to find out the month with the highest number of rainy days. 


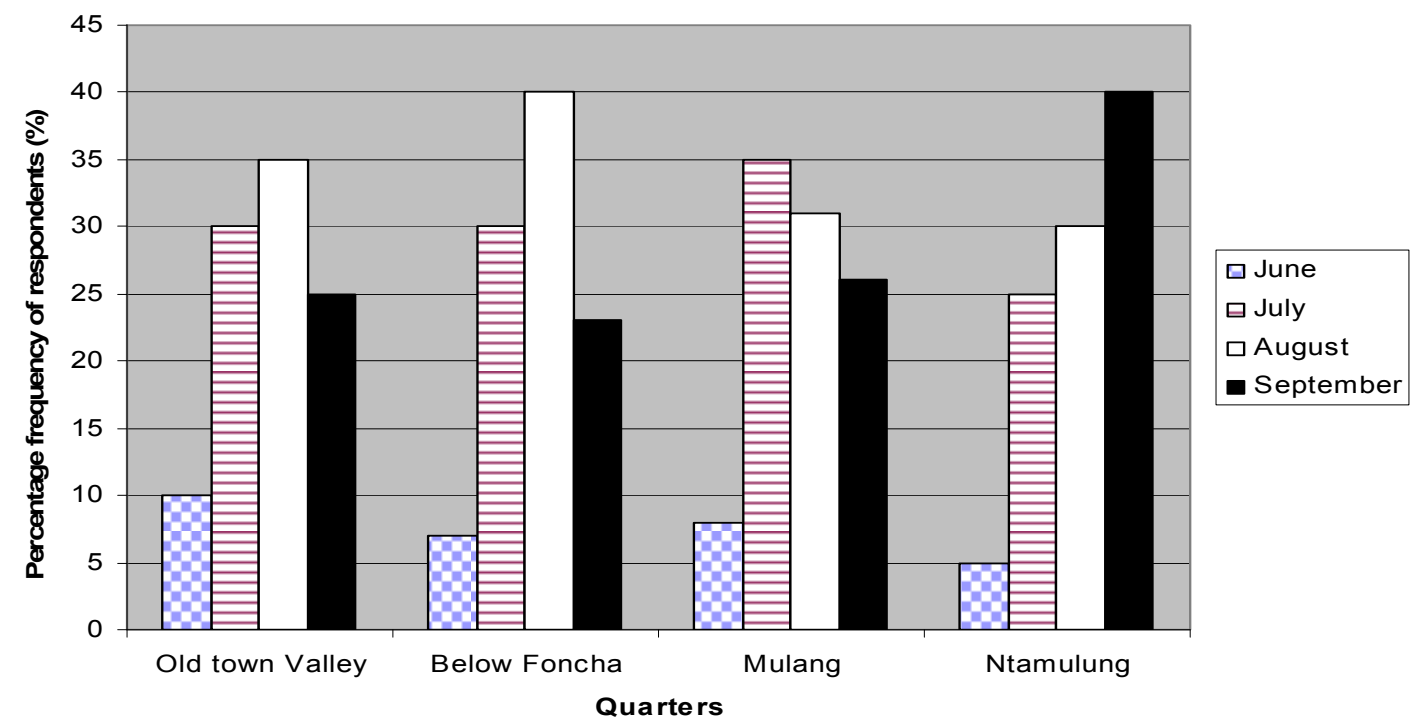

Figure 3. Respondents' perception on the month in which the incidence of floods is common in some quarters in Bamenda

The figure shows the perception of respondents with respect to the months and residential quarters for which flooding is most common. It shows that the highest amounts of rainfall occur in the months of July, August and September.

In examining the spatial variation of the total number of rainy days alongside the incidence of floods, it was discovered that the months of July and August experienced the highest frequency of floods owing to the fact that they recorded the highest number of rainy days in the year 2009. It should be noted that very few incidents of floods were recorded in Bamenda before 1980 (Table 2). Despite heavy rains in the months of July, August and September, most streams were capable of containing large volumes of water within their channels. Though the expanding population of Bamenda is a vital source of development, it brings with it plenty of hydrological problems especially when it exceeds the threshold limits of the support system. Unless the relationship between the multiplying population and the life-support system is stabilized in Bamenda, urban development programmes no matter how innovative, are not likely to yield the desired results. A recent upsurge of urban development in Bamenda is the extension of the foundations of buildings into stream channels. This has increased the intensity and magnitude of floods in Bamenda, constricting if not reducing the sizes of these urban water ways and consequently reducing their carrying capacities. Population increase has come along with an increase in solid waste production, some of which is directly dumped into streams and storm drains, which are already too small to carry runoff. From field evidence, $60 \%$ of those sampled in Small Mankon dump their waste in stream courses, $20 \%$ in drains, $15 \%$ at roadside dumps and $5 \%$ in the Bamenda City Council Van. These water ways are clogged by wastes and in the event of heavy rainfall, floods occur.

The illegal dumping of garbage into the River Mezam for example, by some inhabitants of the town has greatly polluted this river, clogging the stream channel so that water flows sluggishly. Furthermore, the sizes of these drains in some areas are grossly inadequate to effect any meaningful impact on the evacuation of runoff. These runoffs are then channeled on to the road as the drains are small and poorly adapted. Over the past decade however, there has been dredging, widening, straightening and deepening of stream channels to reduce flood risks. These have been effective but more still needs to be done. Besides, the sedimentation of farms, homes, buildings, bridges, and communication systems are other primary effects of flooding in Bamenda (Table 2). Secondary effects include the short-term pollution of rivers and the displacement of persons who have lost their homes. The constant reoccurrence of floods in Bamenda has created the crucial need for new strategies to mitigate this hazard. In this light, inhabitants residing in flood-prone areas have adopted a number of indigenous strategies (Table 3). The chi-square test was used to verify the causes of floods in Bamenda. Using responses from six randomly selected quarters in Bamenda where floods are common, the opinions of respondents on the periods of flood occurrence (before 1980 and after 1980) were taken into consideration. With a degree of freedom of 5 , at the .05 level of significance, the calculated chi-square value was 13.16 . Since the calculated 
chi-square value is greater than the critical value of 11.07 , we concluded that there is reliable evidence that the increasing rate of urbanisation and urban development is the root cause of floods in Bamenda.

Table 2. Devastating effects of floods in some quarters of Bamenda

\begin{tabular}{|c|c|c|}
\hline Year & Affected Quarters & Flood events \\
\hline 1995 & $\begin{array}{c}\text { Mulang, Small Mankon, Ndamukong, Below } \\
\text { Foncha. }\end{array}$ & Death of 2 people and destruction of property \\
\hline 1998 & $\begin{array}{l}\text { Old Town Valley, Ntamulung, Mulang, Below } \\
\text { Foncha. }\end{array}$ & $\begin{array}{l}\text { Three deaths recorded. Destruction of houses } \\
\text { and farmlands }\end{array}$ \\
\hline 1999 & $\begin{array}{c}\text { New layout, Mulang, Below Foncha Old } \\
\text { Town Valley, Bayelle }\end{array}$ & One death Recorded \\
\hline 2000 & Mulang, Below Foncha. & Three deaths recorded \\
\hline 2001 & Ntamulung. & One death recorded \\
\hline 2004 & Below Foncha, Musang & One death recorded \\
\hline 2005 & Musang, Mulang, Below Foncha, Ngomgham. & Death of one child and destruction of property \\
\hline $\begin{array}{l}\text { September } \\
2009\end{array}$ & $\begin{array}{l}\text { Below Foncha, Mulang, Ntamulung, Old } \\
\text { Town Valley, Sisia, New layout. }\end{array}$ & $\begin{array}{l}\text { Two deaths recorded. Destruction of property } \\
\text { and farmlands }\end{array}$ \\
\hline August 2009 & Below Foncha, Old Town valley, Bayelle & $\begin{array}{l}\text { Two deaths recorded besides massive } \\
\text { destruction of property. }\end{array}$ \\
\hline
\end{tabular}

The table shows the devastation by floods for some quarters of the Bamenda Municipal area from 1995 to 2009 . This is reflected in the loss oflives and destruction of property. Source: Compiled from Chumbom (2002), Mengdjo (2009) and field work (2009).

Table 3. Strategies used in combating floods in Bamenda

\begin{tabular}{lc}
\hline Methods Used & \multicolumn{1}{c}{ Reasons } \\
\hline - Building of Levees & $\begin{array}{c}\text { Raise the banks of stream channels so as to confine flood } \\
\text { water within the channel in the event of an increase in } \\
\text { precipitation. }\end{array}$ \\
$\begin{array}{l}\text { Straightening as } \\
\text { well as enlarging of } \\
\text { Stream Channels }\end{array}$ & $\begin{array}{c}\text { Done to increase the size of stream channels in order to } \\
\text { contain excess flood waters as well as to increase the velocity } \\
\text { of flow. }\end{array}$ \\
- $\begin{array}{l}\text { Cleaning up wastes } \\
\text { from storm drains }\end{array}$ & $\begin{array}{c}\text { Done to ensure easy passage of water from drains into } \\
\text { streams. This method increases the velocity of flow thereby } \\
\text { reducing the rate at which paved roads serve as passage ways } \\
\text { for flood waters. }\end{array}$ \\
$\begin{array}{l}\text { Building of solid } \\
\text { embankments at } \\
\text { bridge points }\end{array}$ & Done to block flood waters from spreading unto roads. \\
\hline
\end{tabular}

The table present some strategies used to combat and mitigate the effects of flooding in Bamenda.

The effects of poorly disposed municipal wastes are enormous since it brings into existence breeding grounds for the spread of diseases. These include bacteria that cause typhoid, cholera and dysentery; viruses that cause hepatitis, and parasitic worms, fluxes and protozoa. Thus, inhabitants of flood-prone as well as other areas of the town are at risk from water pollution. Data gotten from the field indicates that the most common water-borne diseases are typhoid (60\%), cholera $(15.7 \%)$ and dysentery $(12 \%)$. The remaining $12 \%$ represents diarrhea and malaria. Since some of the poor urban dwellers depend on streams and wells which for the most part are 
seriously polluted for their daily domestic water requirements, the preponderance of water-borne diseases is a condition sine qua non. In order to curb the problem of illegal waste disposal in Bamenda, the city of Dordrecht in Holland donated two modern garbage vans popularly known as 'Keep Bamenda Clean', hundreds of garbage bins and accessories to sustain the service. The acquisition of these waste disposal equipment enabled the council to create a department of solid waste collection. This has significantly reduced the quantity of wastes deposited in streams in Bamenda. These wastes are then carried and dumped at a local landfill created by the City Council at Mile 6 (Mankon).

\section{Discussion}

The forces behind the occurrence of landslides in Bamenda include the precarious geological condition of the Bamenda escarpment made up of trachy - rhyolites, topography (aspect), climate, vegetation, the suspended nature of the water table, as well as anthropogenic activities masterminded by the rapid rate of urbanisation and urban development. Rapid population growth in Bamenda has imposed stresses on the urban ecosystem as well as incredible urban management problems. People have largely disobeyed building rules such that we now have unorganized and chaotic urban landscape especially at Sisia I and Abaingoh, where houses are randomly built on steep slopes without land certificates and building plans. The immediate trigger for floods is an increase in the amount and intensity of rainfall. However, increased human impacts brought about by urbanisation and urban development have increased the intensity of floods. The disposal of solid wastes in streams and drains has increased the intensity and magnitude of floods. Urbanisation and urban development have led to an ever-increasing amount of littering and the dumping of wastes. Dumps on roadsides, open drains and open spaces in some areas of the town approximate to an ecological disaster. This situation is indeed a tragic irony and quite worrying because most of these wastes have ended up in streams leading to severe water pollution as well as floods. Consequently, most streams that flow through the town of Bamenda are laterally open sewers. Given the disturbing extent of the problems noted and addressed, ensuring a sustainable urban growth for the town should begin with the efficient placement of infrastructure and zoning. People inhabiting hazard-prone areas should be schooled on the fact that urban development is fundamental to human well-being but that growth fails to recognize the limits to natural resources as it could lead to the occurrence of environmental problems and therefore a long-term decline in the quality of life.

The municipal authorities of this city should ensure that the master plan drawn in 1985 is updated. The pattern projected by this plan should be based on housing, open space, circulation and land use demands. Data should be collected based on specific areas where hazards are common and policies should be developed that delineate specific land uses. It is thus necessary to identify areas where landslides are likely to occur and design engineering structures to mitigate their occurrence. Monitoring and mapping techniques will facilitate the identification of hazardous sites. Therefore, the constant occurrence of landslides in Bamenda could be hypothesized as fortunate indicators of what could happen tomorrow. Application of this concept requires mapping both the landslide and the set of geological and morphological factors. It will also necessitate the establishment of a landslides hazard model. as well as establishment of a hazard model. The preparation of landslide hazard and risk maps is required as a base for rational land use planning.

The constant occurrence of floods in Bamenda has remained a painful reminder of the power of nature in the lives of those inhabiting flood-prone areas. The need for improved hazard speculation, preparation and avoidance strategies should be given top priority in relation to the allocation of resources. Self-help for long-term mitigation should be encouraged. Experience shows that large-scale eviction and forced relocation can exacerbate social problems which can be more problematic for urban authorities than the floods. As the demand for land increases, it is not possible to assign land purely for flood management purposes. Therefore, an alternative land use model is essential to ensure that informal settlements do not re-appear (Kometa, 2005). The land, biomass and water supplies of Bamenda are greatly affected by the process of urbanisation and urban development such that development itself is put into jeopardy. It is important to realize that sustainable urban development is fundamental for the well-being of the population. Therefore we must try as much as possible to understand the manner in which the earth works in order to sustainably utilize and enjoy the benefits or resources. Drawing from the findings in this research, sustainable urban development is the only way forward if Bamenda is to be freed from the shackles of urban environmental hazards. Consequently, a panacea to reduce the actual and potential damage borne by urbanization is to plan Bamenda in a manner in which most of these adverse implications can be neutralized. Integrated urban environmental planning is required in order to achieve a sustainable urban space management. 


\section{Conclusion}

In order to achieve sustainable urban planning in Bamenda and check hazardous development especially in landslide as well as flood-prone areas, it is necessary that authorities in urban development generate succinct planning models so that every bit of available land in the area is used in the most rational and optimal way. This requires considering the present and past land use/land cover information of the area and patterns of change, with respect to areas liable to hydrological as well as geomorphological hazards. Thus, the concept of sustainable urban development should embrace not just environmental issues but should also extend into people's life styles. In essence therefore, two broad approaches should be implemented to achieve sustainable urban development in which the negative hydro-geomorphological implications can be averted. These include; an environmental protection approach with a focus on municipal programmes through the education of citizens on the triggers of urban geomorphological/hydrological hazards and a holistic approach including an ecological component (stressing the ecological importance of environmentally sound policies), economic aspects (urban development activities) as well as social equity issues and the distributional impact of these policies.

\section{References}

Acho-Chi, C. (1998). Human Interphase and Environmental Instability: Addressing the Environmental Problems of Rapid Urban Growth. Environment and Urbanization, 10(2).

Ayaode, J. O. (1988). Introduction to Climatology for the Tropics Spectrum Books Limited Ibadan. Nigeria.

Ayonghe, S. N., Mafany, G. T., Ntasin, E., \& Samalang, P. (1999). Natural Hazards, 19, 13-27. Netherlands: Kluver Academic Publishers.

Bamenda Master Plan. (1985). Sectoral Analysis and Diagnosis, Ministry of Urban Development and Housing.

Bamenda Master Plan. (1985). Main Report, Ministry of Urban Development and Housing.

Ban, K. M. (2000). State of the World's Cities, Harmonious Cities. U. N Habitat. London: Earthscan.

Barrow, C. J. (1995). Developing the Environment. Problems and Management. Cambridge University Press.

Carrara, A., \& Guzzette, F. (1995). Geographical Information Systems in Assessing Natural Hazards. Dortretch: Kluwer Academic Publishers.

Faniran, A., \& Jeje, L. K. (2002). Humid tropical geomorphology. New York: Longman Inc.

Feisc, B., Rogers, P., \& John, R. (1998). People and the Earth. Basic Issues in the Sustainability of Resources and the Environment. Cambridge University Press.

Goudie, A. (1993). The Human Impact on the Natural Environment (4th ed.). Blackwell Publishers.

Gruden, D. M. (1991). Landslide Type and Processes. In Turner, A. K., \& Schuster, R. L. (Eds.), Investigation and Mitigation. Washington: National Academy Press.

Hardoy, J. E. (1992). Environmental Problems in Third World Cities. London: Earthscan.

Kometa, S. S. (2005). The Impacts $f$ Man - Induced Hazards in Fako Division, South West Region f Cameroon. Unpublished Ph. D.Thesis, University of Buea.

Lambi, C. M. (2004). A Revisit of the Recurrent Landslides On The Bamenda Escarpment (North West Province Of Cameroon). Journal of Applied Social Sciences, 4(1).

Lambi, C. M., \& Fogwe, F. (2001). The February 2000 Floods in Down Town Yaounde. In Lambi, C., \& Eze, B. (Eds.), Readings in Geography. Unique Printers, Bamenda, Cameroon.

Nchinda, H. (2004). Solid Waste Management in Bamenda. In The Geographer Vol. 3. Published by North West Geography Teacher's Association (NOWEGTA).

Ndenecho, E. N. (2007). Landslide and Torrent - Channel Problems of Mountain Slopes. Unique Printers Bamenda.

Ndenecho, E. N., \& Eze, B. (2004). Geomorphic and Anthropogenic Factors Influencing Landslides in the Bamenda Highlands (North West Province, Cameroon). Journal of Applied Social Sciences, 4(1).

Neba, A. (1999). Modern Geography of the Republic of Cameroon (3rd ed.). Cameroon: Neba PublishersBamenda.

Nick, M. (1995). The Global Casino. An Introduction to Environmental Issues. U.S.A: John Wiley and Sons, Inc. 
Owen, L. A., \& Kelvin, T. P. (1994). An Introduction to Global Environmental Issues. London: Butler and Tammer limited.

Park, C. (2001). The Environment, Principles and Applications (2nd ed.). London, Routledge.

Sule, R. O. (2007). Urban Planning administration and Environmental Health Criticality. Lagos: Thumprints International Company. 